Filip Bolechała, Marcin Strona

\title{
Niecodzienny przypadek samobójczego zatrucia tlenkiem węgla przy użyciu przenośnego grilla ogrodowego *
}

\author{
An unusual case of suicidal carbon monoxide poisoning committed using \\ a portable barbecue grill
}

\author{
Z Katedry i Zakładu Medycyny Sądowej UJ CM \\ Kierownik: prof. dr hab. med. M. Kłys
}

Śmiertelne zatrucia tlenkiem węgla są dość często spotykane w praktyce medyczno-sądowej. Choć zazwyczaj mamy wówczas do czynienia ze zdarzeniami o charakterze nieszczęśliwego wypadku, to przypadki zatruć samobójczych też nie należą do rzadkości - tak w Polsce, jak również w innych krajach europejskich. Źródłem trującego gazu, mającego posłużyć samobójcy do odebrania sobie życia, bywają zazwyczaj spaliny silników samochodowych i domowych piecyków gazowych w instalacjach podgrzewających wodę uwalniane w zamkniętych pomieszczeniach. W niniejszej pracy pragniemy przedstawić nietypowy przypadek, jedyny w historii krakowskiego Zakładu, w którym do uzyskania wysokiego stężenia tlenku węgla wykorzystano palące się brykiety węglowe $w$ typowym, przenośnym grillu ogrodowym. Liczący 65 lat mężczyzna rozpalił go w zamkniętym od wewnątrz pokoju, gdzie wcześniej uszczelnił wszystkie szpary i otwory wentylacyjne, a przy wejściu zostawił kartkę ostrzegającą współmieszkańców o obecności gazu. Ustalenia śledcze wskazały, że podłożem targnięcia się na własne życie były przede wszystkim kłopoty zdrowotne. Z analizy piśmiennictwa wynika, że taki sposób samobójstwa (mimo dużej dostępności materiałów) należy do wyjątkowej rzadkości w kulturze europejskiej czy amerykańskiej, gdzie literatura przynosi opisy tylko pojedynczych przypadków. Natomiast zwrócono uwagę, iż wykorzystywanie grillów do samobójczych zatruć stało się w ostatnich kilkunastu latach niezwykle powszechne w krajach Dalekiego Wschodu. Wskaza- no pewne historyczno-kulturowe uwarunkowania mogące mieć wpływ na tak wyraźną geograficzną polaryzację występowania omawianej metody w niektórych państwach azjatyckich oraz przytoczono dyskutowaną w piśmiennictwie naukowym znaczącą rolę mediów w popularyzacji takiego sposobu samobójstwa.

Fatal carbon monoxide poisoning is relatively often encountered in medico-legal practice. Although we usually deal with events of an accidental nature, cases of suicidal character are also quite common, both in Poland and in other European countries. The source of a poisonous gas that is used by a suicide to take his life are usually exhaust fumes from cars and home gas water-heaters that are released in closed spaces. In the present report, the authors present an atypical case - the only such instance in the history of the Krakow Department - where a high carbon monoxide concentration level was achieved by burning briquetted coal in a typical portable barbecue grill. A 65-year old male lit the grill in a room locked from inside, where he had previously sealed all cracks and vents; he left a written message by the entrance where he warned his flatmates about the presence of gas. The investigation determined that the predominant underlying reason of his committing suicide were health problems. As it follows from the analysis of literature on the subject, despite extensively available materials, such a suicide method is exceptionally rare in the European or American culture,

\footnotetext{
* Poszerzona wersja referatu przedstawionego podczas Międzynarodowej Konferencji „Kryminalistyka, Policja, Bezpieczeństwo” z okazji 55-lecia powstania Laboratorium Kryminalistycznego KWP w Krakowie, Kraków 26-28.09.2012
} 
where isolated cases only are presented. On the other hand, the authors emphasize the fact that within the last score of years, using barbecue grills in suicidal poisoning has become exceedingly common in the Far East countries. The present report points to certain historical and cultural determinants that may affect such a distinct geographical polarization of the discussed method being used in some Asian countries and refers to a widely discussed by specialists significant role of mass media in popularization of such a suicide method.

Słowa kluczowe: samobójstwo, zatrucie, tlenek węgla, grill Key words:

suicide, poisoning, carbon monoxide, grill

\section{WSTĘP}

Przywołując i opisując niniejszy przypadek na myśl przychodzi łacińska sentencja "non nova sed nove", co oznacza "nic nowego ale w nowy sposób podane". Śmiertelne zatrucia tlenkiem węgla są dość często spotykane w praktyce badań i opinii medyczno-sądowych. W krakowskim Zakładzie Medycyny Sądowej obecnie wykonuje się rocznie około dwudziestu kilku do trzydziestu paru sekcji zwłok, w których przyczyną zgonu jest toksyczne działanie tlenku węgla. Podobnie wygląda sytuacja w innych tego typu jednostkach w Polsce [1]. Badania pośmiertne dotyczą zazwyczaj przypadków ostrych zatruć mających charakter nieszczęśliwego wypadku poprzez przebywanie ludzi w atmosferze podwyższonego stężenia tlenku węgla w powietrzu. Zdarza się to najczęściej na skutek różnego typu pożarów i niekontrolowanego palenia się materiałów, wadliwości domowych urządzeń gazowych lub instalacji wentylacyjno-kominowych (piecyki łazienkowe i kuchenne, piece akumulacyjne opalane węglem), uwalniania się spalin samochodowych podczas prac w zamkniętych pomieszczeniach (garaże), wchodzenia do miejsc, gdzie nagromadził się trujący gaz (zakłady produkcyjne) itp. [1, 2, 3, 4]. Spotykane są również, choć znacznie rzadziej, przypadki śmiertelnych zatruć będących działaniem celowym. Są to zdarzenia pojedyncze i stanowią co najwyżej kilka procent wszystkich skutecznych, zakończonych zgonem, zatruć samobójczych $[5,6]$.
W takich sytuacjach źródłem tlenku węgla bywają z reguły spaliny silników samochodowych oraz domowych piecyków gazowych w instalacjach podgrzewających wodę, uwalniane w sposób planowy i przemyślany do zamkniętych pomieszczeń. W niniejszej pracy pragniemy przedstawić nietypowy przypadek, jedyny w historii krakowskiego Zakładu, w którym do uzyskania wysokiego stężenia tlenku węgla wykorzystano palące się brykiety węglowe w typowym, przenośnym grillu ogrodowym.

\section{OPIS PRZYPADKU}

W październiku 2007 roku dyżurny jednego z komisariatów policji w Krakowie przyjął zawiadomienie o podejrzeniu próby popełnienia samobójstwa przez X, mężczyzny w wieku 65 lat. Zgłoszenia dokonała jego żona $Y$, która została zaalarmowana telefonicznie przez dwie córki o braku możliwości dostania się do domu. Po przyjeździe na miejsce $Y$ weszła do budynku przez garaż. Na drzwiach jednego z pokoi, który był zamknięty od środka na klucz zobaczyła przyklejoną kartkę z odręcznie napisanym ostrzeżeniem w języku słowackim i angielskim. Informowała ona, że w domu jest gaz tlenek węgla i należy najpierw otworzyć wszystkie okna oraz drzwi. Kobieta pukała do pokoju, jednak nikt nie odpowiadał.

Przybyli na miejsce zdarzenia policjanci i strażacy PSP dokonali siłowego otwarcia zamkniętych drzwi. Po wejściu do pokoju znaleziono leżącego na podłodze przy wejściu $X$, który nie dawał oznak życia. Powietrze w pomieszczeniu było silnie zadymione z wyczuwalną wonią spalenizny. Lekarz pogotowia ratunkowego podjął czynności reanimacyjne, które nie przyniosły powodzenia i stwierdził zgon mężczyzny.

Podczas oględzin stwierdzono, że miejscem zdarzenia jest pokój na poddaszu o wymiarach około 7x5 metrów w domu jednorodzinnym, posiadający dwa zamknięte szczelnie okna (zwykłe i dachowe) oraz drzwi, umeblowany w łóżko, komodę, stolik nocny i zestaw telewizyjny. Na środku pokoju stał metalowy, przenośny grill ogrodowy na nóżkach, ciepły w dotyku, a w obrębie jego paleniska był wypalony całkowicie, szary popiół. Obok pod ścianą znajdował się worek z brykietami węgla drzewnego i akcesoria grillowe. Na podłodze obok zwłok leżała kartka papieru A4 z odręczną notatką. Ponadto 
ujawniono, że szczelina między skrzydłem drzwi i framugą została szczelnie oklejona taśmą samoprzylepną przymocowaną do ich brzegów. Podobnie zaklejony został wylot wentylacyjny klimatyzatora umieszczonego na ścianie oraz otwór na klucz w drzwiach. Znajdujący się w pokoju na jednej ze ścian czujnik dymu alarmu przeciwpożarowego był zakryty skarpetką.

Y zeznała, że jej mąż nie pracował od długiego czasu ze względu na przewlekłe, liczne schorzenia. Podała, że od ponad dwudziestu lat cierpiał na depresję, przewlekłe zmęczenie, zmiany w mózgu o typie zwapnień i w objawach podobne do choroby Parkinsona. W 1998 roku X, przeszedł operację wszczepienia implantów w obrębie szyjnego odcinka kręgosłupa. W 2004 rozpoznano u niego zmianę nowotworową w mózgu i z tego powodu miał wykonywany zabieg, którego pozostałością był niedowład części twarzy. Latem 2007 roku ponownie pojawiły się dolegliwości bólowe kręgosłupa szyjnego. Przeprowadzona diagnostyka wskazywała na konieczność kolejnej operacji, o której wiadomo było jednak, że opatrzona jest bardzo znacznym ryzykiem niepowodzenia i możliwości paraliżu. Na dzień przed śmiercią $X$ odebrał wynik badania CT kręgosłupa szyjnego, wykonanego w Krakowskim Szpitalu Specjalistycznym im. Jana Pawła II, które wykazało między innymi: stan po zespoleniu blaszką od strony przedniej trzonów kręgów C5-C7, zwężenie przestrzeni międzytrzonowej C4-C5 z uwypukleniem krążka międzykręgowego w kierunku kanału i uciskiem na worek oponowy, zmiany wytwórcze z osteofitami skierowanymi do kanału kręgowego, drobnymi wolnymi ciałami kostnymi i zwapnieniami w więzadle podłużnym tylnym, zwężenie przestrzeni międzytrzonowych C5-C7 z tworzącymi się blokami kostnymi. Y podała, że ze względu na wszystkie swoje choroby jej mąż był osobą bardzo nieszczęśliwą. Nie był załamany nerwowo, ale twierdził, że każda kolejna operacja prowadzi do pogorszenia zdrowia. Odczuwał ponadto nieustanne poczucie uzależnienia od żony (która była wówczas kierownikiem finansowym w dużej firmie), co dodatkowo skutkowało pogorszeniem jego stanu psychicznego. W przeszłości około roku 2001/2002 X miał wspominać synowi z pierwszego małżeństwa o zamiarze popełnienia samobójstwa. Później nigdy już takich myśli nie wyrażał.

Co do bezpośrednich okoliczności zdarzenia $Y$ zeznała, że X widziała ostatni raz tego samego dnia około godz. 8:00. Mąż został sam w domu. Dzwoniła do niego około godz. 13:00 ale nie odbierał telefonu. Córki wróciły do domu około godz. 17:00 i ponieważ nie mogły dostać się do środka zadzwoniły do matki. Około godz. 18:00 Y przyjechała z pracy. Po wejściu policji, straży pożarnej i pogotowia ratunkowego w pokoju, w którym ujawniono zwłoki $X$ znalazła leki nasenne używane przez męża. Według niej brakowało około 120 tabletek. Znalazła też pustą butelkę po wódce i butelkę z wodą oraz list pożegnalny, w którym wyjaśniał, że „nie może tak dłużej żyć, za dużo cierpi i tak jak zrobił będzie lepiej dla wszystkich".

Dnia 27.10.2007 roku w Zakładzie Medycyny Sądowej UJ CM przeprowadzono sekcję zwłok X. Badaniem pośmiertnym stwierdzono: różowo-żywoczerwone zabarwienie plam opadowych i narządów wewnętrznych, obrzęk płuc, nieznaczną miażdżycę aorty i tętnic wieńcowych serca, powiększenie śledziony, przekrwienie narządów wewnętrznych, stan po przeprowadzonej w przeszłości operacji w obrębie jamy czaszki (prawostronna kraniotomia skroniowa) i stan po przebytej operacji kręgosłupa szyjnego z zespoleniem kręgów C5-C7 metalową blaszką. W żołądku obecny był różowawy płyn z białawymi drobinami. Badaniem toksykologicznym stwierdzono we krwi zmarłego obecność alkoholu etylowego w stężeniu $1.3 \%$, a w moczu $0.7 \%$. Oznaczono poziom hemoglobiny tlenkowęglowej, który wynosił 70 \%. Prokuratura zleciła tylko podstawowe, przesiewowe badania chemiczno-toksykologiczne z użyciem testów immunologicznych, które w moczu zmarłego wykazały obecność leków z grupy pochodnych 1,4-benzodiazepiny i trójcyklicznych antydepresantów. Na podstawie wyników przeprowadzonych badań pośmiertnych oraz informacji z materiału aktowego przyjęto, że przyczyną zgonu $X$ było ostre zatrucie tlenkiem węgla uwalnianym podczas palenia w grillu.

\section{DYSKUSJA}

Przegląd piśmiennictwa światowego wskazuje, że na przestrzeni wielu ostatnich lat w Europie i Ameryce Północnej obserwuje się wyraźny spadek liczby samobójstw dokonywanych poprzez zatrucie tlenkiem węgla, które do pierwszej połowy XX wieku stanowiło jedną z najczęściej wybieranych 
metod $[4,5,7,8,9,10]$. Najistotniejszy wpływ na to miały przeprowadzane stopniowo w większości krajów zmiany składu gazu opałowego dostarczanego do gospodarstw domowych. Tym samym utrudniono dostęp do tlenku węgla mającego posłużyć celom samobójczym, a uzyskanie planowanego efektu zaczęło wymagać bardziej złożonych działań. Najczęściej spotykano się wówczas z demontażem instalacji odprowadzających spaliny z domowych piecyków gazowych, odpalaniem silników samochodowych w zamkniętych pomieszczeniach garażowych, doprowadzaniem spalin silnikowych do wnętrza pojazdu.

Grillowanie to smażenie żywności na ruszcie umieszczonym bezpośrednio nad źródłem ciepła, które znane jest od czasów prehistorycznych. Współcześnie ta metoda przyrządzania jedzenia upowszechniła się szeroko na całym świecie ze względu na szeroką dostępność i niewielki koszt eksploatacji, stanowiąc bardzo popularną okazję do towarzyskich spotkań na otwartym powietrzu, zarówno w miastach, wsiach jak i podczas wycieczek plenerowych. Grill, będący urządzeniem do cieplnej obróbki produktów żywnościowych, może mieć formę przypominającą nieco wolnostojący kominek żeliwny, ceglany lub kamienny oraz znacznie powszechniejszą, tańszą i poręczniejszą - przenośną, zazwyczaj metalową (wiele wariantów). Ze względu na źródło energii rozróżnia się grille drewniane, gazowe, elektryczne i węglowe. W tych ostatnich ciepło uzyskuje się poprzez palenie węgla drzewnego do otrzymania tzw. żaru. Ten rodzaj spalania ze względu na swój powolny, niezupełny charakter jest źródłem dużej ilości dymu i tlenku węgla, które jednak nie stanowią żadnego niebezpieczeństwa w przypadku grillowania na wolnym powietrzu. Pomimo tak ogromnej dostępności i powszechności grillów, to sytuacje rozmyślnego wykorzystania ich w celach samobójczych spotykane są w Europie i Ameryce Północnej bardzo rzadko, a literatura przynosi opisy tylko pojedynczych zdarzeń $[11,12,13,14]$. W dostępnym piśmiennictwie naukowym nie znaleziono natomiast żadnych, nawet kazuistycznych opisów takich samobójstw w Ameryce Środkowej i Południowej, europejskich krajach basenu Morza Śródziemnego, Afryce, na Bliskim Wschodzie, Australii czy Azji Centralnej i Południowej. Najprawdopodobniej wynika to z kulturowych i kulinarnych uwarunkowań wyko- rzystywania z reguły w tych regionach świata grillów stacjonarnych, a nie przenośnych.

Podobnie, ale tylko do połowy lat dziewięćdziesiątych XX wieku wyglądała sytuacja w azjatyckich krajach Dalekiego Wschodu [15, 16, 17, 18, 19, 20, 21]. W listopadzie 1998 roku pewna kobieta w Hong-Kongu popełniła samobójstwo rozpalając grilla węglowego w sypialni własnego mieszkania. Do tego czasu nie obserwowano i nie opisywano takiego sposobu odbierania sobie życia, a samobójcze zatrucia tlenkiem węgla należały do pojedynczych przypadków. Najprawdopodobniej prekursorską inspiracją były informacje z pewnego filmu (zastosowanie tradycyjnego dla Chin i Japonii, przenośnego piecyka kuchennego - „hibachi”) oraz chemiczno-inżynieryjne wykształcenie samobójczyni. Przypadek ten został ze szczegółami przedstawiony w lokalnych mediach, prezentując się na czołówkach gazet oraz telewizyjnych i radiowych wiadomości. Od tego momentu nastąpił lawinowy wzrost samobójstw przez zatrucie tlenkiem węgla przy użyciu rozpalonego grilla, który rozprzestrzenił się szeroko na inne kraje regionu (Tajwan, Chiny, Korea Pd., Japonia). W roku 1999 metoda ta stanowiła już 10.1\% wszystkich samobójstw dokonanych w Hong-Kongu (56 zgonów od listopada 1998 do grudnia 1999), a w 2001 stała się drugim co do częstości sposobem odebrania sobie życia obejmując około $25 \%$ wszystkich przypadków. Sytuacja ta zmusiła władze do wprowadzenia ogólnokrajowego programu zastępowania grillów węglowych przez elektryczne. Na Tajwanie współczynnik samobójstw przy użyciu węglowego grilla wzrósł z 0.22 na 100 tys. mieszkańców w roku 1999 do 6.48/100 tys. w 2006 roku. W Japonii opisywana metoda stała się najbardziej popularnym sposobem popełniania samobójstw grupowych, w których osoby umawiały się i zawierały przymierze (tzw. „suicide pact”) z wykorzystaniem internetu, a następnie w tym samym czasie odbierały sobie życie. W ten sposób w 2003 roku zginęło w tym kraju ponad 3500 osób!

Omawiając niniejsze zagadnienia nie sposób pominąć roli środków masowego przekazu w kształtowaniu nowych zachowań i trendów społecznych. Znaczenie mediów jako źródła informacji dla osób pragnących odebrać sobie życie, swoistego elementarza samobójców oraz inspiracji do określonych działań jest przedmiotem szerokiej analizy i dyskusji 
naukowej na wielu płaszczyznach, od dziedzin humanistycznych po biologiczne. Niebagatelne znaczenie ma w tych kwestiach siła, szybkość, łatwość dostępu i powszechność rozprzestrzeniania się wiadomości za pośrednictwem telewizji lub internetu. Należy zwrócić uwagę, że zaprezentowanie po raz pierwszy w mediach Hong-Kongu przypadku zatrucia tlenkiem węgla z wykorzystaniem węglowego grilla zaowocowało w kolejnych dziewięciu tygodniach 22 przypadkami podobnych samobójstw, podczas gdy wcześniej nie odnotowano ani jednego („,copycat effect”). Podobną sytuację obserwowano na Tajwanie, w Japonii czy w Korei Pd. Na początku lat dwutysięcznych opisywany sposób samobójstwa dotarł również do Europy, na szczęście jak dotychczas w postaci pojedynczych przypadków.

\section{WNIOSKI}

Z punktu widzenia społeczności europejskiej wydaje się zaskakujące tak masowe rozprzestrzenianie się nowej metody samobójstwa oraz wykorzy-

\section{PIŚMIENNICTWO}

1. Wardaszka Z., Ptaszyńska-Sarosiek I., Niemcunowicz-Janica A.: Zatrucia tlenkiem węgla w materiale sekcyjnym Zakładu Medycyny Sądowej UM w Białymstoku w latach 1998-2008. Arch. Med. Sąd. Kryminol. 2009; 59: 177-182.

2. Jaklińska A., Chagowski W.: Śmiertelne zatrucia tlenkiem węgla $w$ materiale sekcyjnym Zakładu Medycyny Sądowej AM w Lublinie. Arch. Med. Sąd. Kryminol. 1987; 37: 121-125.

3. Brodziak T., Kołowski J., Żaba C.: Zatrucie tlenkiem węgla w materiale sekcyjnym Zakładu Medycyny Sądowej Akademii Medycznej w Poznaniu w latach 1950-1991. Arch. Med. Sąd. Kryminol. 1993; 43: 212-221.

4. Duda U., Kłys M., Trela F.: Zatrucia śmiertelne tlenkiem węgla w materiale sekcyjnym Zakładu Medycyny Sądowej w Krakowie w latach 1947-1996. Arch. Med. Sąd. Kryminol. 1997; 47 : 197-208. stywanie jej w sposób niespotykany dla naszej kultury i sposobu myślenia. Niewątpliwie decydujące znaczenie miały tu pewne kulturowe uwarunkowania w zderzeniu z wielką siłą przekazu nowoczesnych źródeł informacji. Być może znaczenie miał również fakt, że pod koniec XX wieku i na początku XXI państwa Azji Południowo-Wschodniej i Japonia, po wcześniejszym rozkwicie, dotknięte zostały poważnym kryzysem gospodarczym, co przekładało się na ogólny wzrost zachowań samobójczych.

Przedstawiliśmy kazuistyczny w naszym kraju przypadek samobójstwa z wykorzystaniem grilla, którego kulinarne zastosowanie jest przecież już od wielu lat na całym świecie czymś łatwo dostępnym, bardzo popularnym i powszechnie używanym. Tym samym autorzy pragnęli również pokazać, jak błyskawicznie nowa metoda potrafi w dzisiejszych czasach globalnej społeczności internetowej znaleźć rzesze naśladowców.

5. Trela F., Kołodziej J., Kunz J., Bolechała F.: Samobójcze zatrucia środkami chemicznymi i lekami w latach 1991-2000 w materiale krakowskiego Zakładu Medycyny Sądowej. Arch. Med. Sąd. Kryminol. 2002; 52: 21-30.

6. Bolechała F., Trela F., Trepińska J., Piotrowicz K., Bąkowski R., Polewka A.: Samobójstwo dokonane - zarys zjawiska na podstawie materiału krakowskiego Zakładu Medycyny Sądowej z lat 1991-2000. Przegl. Lek. 2006; 63: 261-264.

7. Kłys M., Baran E.: Zatrucia śmiertelne w materiale Zakładu Medycyny Sądowej w Krakowie w latach 1946-1995. Arch. Med. Sąd. Kryminol. 1996; 46: 277-287.

8. Marek Z., Kołodziej J., Baran E.: Samobójstwa w Krakowie - badania porównawcze z lat 1881-1990. Arch. Med. Sąd. Kryminol. 1991; 41: 241$-247$.

9. Evans G., Farberow N.: The encyclopedia of suicide. New York: Facts On File; 1988.

10. Maris R., Berman A., Silverman M.: Compre- 
hensive textbook of suicidology. New York: The Guilford Press; 2000.

11. Patel F.: Carbon copy deaths: carbon monoxide gas chamber. J Forensic Leg Med. 2008; 15: 398-401.

12. Wirthl I., Schulz R., Schmeling A.: Suicide by means of a charcoal grill. Casuistic report with review of literature. Arch. Kriminol. 2008; 221 : 129-137.

13. Hartwig S., Tsokos M.: Suicidal and accidental carbon monoxide poisonings due to charcoal fires in closed spaces. Arch Kriminol. 2008; 222: 1-13.

14. Brooks-Lim E. W., Sadler D. W.: Suicide by burning charcoal: three case reports. Med Sci Law. 2009; 49: 301-306.

15. Wai Sau D. Ch., Chi Ming L.: Carbon monoxide poisoning as a new method of suicide in Hong Kong. Psychiatr Serv. 2001; 52: 836-837.

16. Leung C. M., Chung W. S., So EP. Burning charcoal: an indigenous method of committing suicide in Hong Kong. J Clin Psychiatry. 2002; 63: 447-450.

17. Chan K. P., Yip P. S., Au J., Lee D. T.: Charcoal-burning suicide in post-transition Hong Kong. Br J Psychiatry. 2005; 186: 67-73.

18. Liu K. Y., Beautrais A., Caine E., et al. Charcoal burning suicides in Hong Kong and urban Taiwan: an illustration of the impact of a novel suicide method on overall regional rates. J Epidemiol Community Health. 2007; 61: 248-253.

19. Naito A.: Internet suicide in Japan: implications for child and adolescent mental health. Clin Child Psychol Psychiatry. 2007; 12: 583-597.

20. Huh G. Y., Jo G. R., Kim K. H., Ahn Y. W., Lee S. Y.: Imitative suicide by burning charcoal in the southeastern region of Korea: The influence of mass media reporting. Leg Med. 2009.

21. Pan Y. J., Liao S. C., Lee M. B.: Suicide by charcoal burning in Taiwan, 1995-2006. J Affect Disord. 2010; 120: 254-257.

Adres do korespondencji:

Katedra i Zakład Medycyny Sądowej UJ CM

ul. Grzegórzecka 16

31-531 Kraków

e-mail: filip.bolechala@uj.edu.pl 